\title{
Artistic Codes of Historical Consciousness in Prose by Boris Pilnyak
}

\author{
Liudmila A. Trubina* \\ Moscow State University of Education \\ 1 M. Pirogovskaya Str., Moscow, 119991, Russia
}

Received 10.01.2017, received in revised form 21.08.2017, accepted 28.08.2017

The present article studies the works by Boris Pilnyak, an avant-guarde writer of the 1920s. We see the prospect of modern interpretation of the author's prose in studying the connection between his formal experiments and ontological background. In this regard, Pilnyak continues the classic tradition, simultaneously starting a dialogue with it, destructing classic formalism.

The present research focuses on the artistic codes, revealing the historical consciousness of the author. In the centre is Pilnyak's original view of Russian history, underlying the stylistic peculiarities of his works. The "fragmentary" composition, some elements of "brain game", system of theme lines altogether work to create the image of "whirled up", "bothered" time. The historiosophical background is expressed through the metaphorized chronotopos, combination of "natural" and "historical" metaphors, symbolization of headlines, names and last names, stylization of folkloric and Orthodox imagery.

Keywords: Boris Pilnyak, literature of the 1920s, avant-guarde, ornamental prose, historiosophy, historical consciousness, metaphor, theme line, symbol, image of time.

DOI: 10.17516/1997-1370-0158.

Research area: philology.

\section{Introduction into the problem}

As we can see from the chronicles of Russian literature, in the 20s of the past century the name of Boris Pilnyak (Vogau) (1894-1938) was one of the dominant ones (Lit. zhizn', 2005). According to his contemporaries, books by Pilnyak presented "nine tenths of fate" of the prose of the Revolution period. "To a certain extent, the sign of Pilnyak happened to be the sign of history, the sign of his age" (Gofman, 1928: 7). With a number of his literary discoveries, Pilnyak became a pioneer among writers later recognized as masters of the world literature (Shaytanov, 1991: 9).

Pilnyak had artistic and friendly relationships with the leading writers of his time. He recited some chapters from "The Naked Year" in the house of A. Voronsky, the chief editor of the "Krasnaia Nov" magazine; M. Gorky received the manuscript of the novel from B. Pasternak, after which Gorky, and, independently, Lunacharsky recommended "The Naked Year" for publishing. The novel brought its author world-wide recognition. We can continue

(C) Siberian Federal University. All rights reserved

* Corresponding author E-mail address: trubina_1@mail.ru 
the list of names with E. Zamyatin, S. Esenin, A. Akhmatova, A. Platonov and other writers, the friends of Pilnyak, fans of his works, and even co-authors of books written in collaboration with him. Later, in the 1980s, V. Shalamov called Pilnyak "the largest name in the literature of the 20s" (Shalamov, 1987: 40).

But today we can hardly speak of wide fame of B. Pilnyak, as well as of knowledge of his works. The reason for the great success of Pilnyak in his time was the bright originality of the writer. Some readers are turned off by his "revolutionary character", others are annoyed by the formal experiments, which (for example, in "Third Capital" have all the features of "brain games", complicating the perception of the plot and suppressing any attempts of speaking of any connection with the tradition and the ontological sense of the writer's artistic world. But this is where we find the prospect for the modern interpretation of the writer's prose.

It appears important to remark Pilnyak's inclination to the problems of history, his desire not only to imprint, but also to comprehend the events in a wide historical context, his participation in the disputes that had been going on in Russia for two hundred years after the reforms of Peter the Great (B. Andronikashvili-Pilnyak, Auer, Griakalova, Voronov, Skorospelova, Trubina, Shaytanov). At the turn of the century, the writer had repeatedly got back to the basics, the roots of the people's life as their only support in the challenges brought by history. With such interpretation of the artistic searches of Pilnyak, the writer seems to be a natural member of one of the leading tendencies of Russian literature we refer to as "historical consciousness" (Trubina, 1999).

\section{Historical consciousness}

\section{as a category of literary criticism}

It is not only literature; the whole Russian thought is "historiosophical all over" (Zen'kovskiy,
1991: 16), focused on the questions of the meaning of history, its end and beginning, the laws of historical development. All contemplations of our cultural luminaries of the meaning of history are recognizable with a special Russian flavour. The authors arrive at the conclusion on universalism typical for philosophy through the comprehension of the fates of their country, their people, through the understanding of the place Russia occupies in the universal, historical and cosmic processes. An inclination for historiosophical reflection, peculiar interest for the fate of Russia and its people, deliberate attention to the past (or "the cult of the past", according to D.S. Likhachev) combined with the criticism of the present and aspiration for the future, with intensive search for the moral righteousness of the historical existence make up the nerve of Russian literature, its main national feature.

The Revolution aggravated the historiosophical tension of artistic search. As noticed by multiple Russian and foreign researchers (N. Berdyaev, E. Troeltsch etc.), the great collapse of existence exacerbated the sense of history. One generation witnessed the "breakup" (B. Lavrenev), the great "stage on the post-chaise route of history" (B. Pilnyak). Having chosen the period of the Revolution as the conceptual focus of their books, the artists worked to comprehend the situation through the historical prism, research the root causes of the conflicts unwinding in front of their eyes, understand their motives and driving force, draw some insightful historical parallels. They created the artistic philosophy of history, sometimes anticipating official historical studies, and, concerning the emotional and psychological impact of literature, also influencing the development of social consciousness. Despite any differences in the opinions, the natural revolutionary intransigence and vibrant political disputes, the artists rose from the purely political 
passions to humanitarian problems. They dared to ask the "cursed" questions the Russian thought had been wrestling with for ages: the questions of revolution and evolution, ends and means, humanism and cruelty, right to violence, solving all issues with the "war". But the major one is the fate of Russia, which, according to N. Berdyaev, is far more valuable than that of social classes and parties, doctrines and theories. This problem is inseparable from the thought of the Russian people at the turn of ages, of the relationships between person and society, people, and nation; the incomprehensible "dapple" of the national character, its historical sustainability and variability.

The Revolution period caused dramatic review of all underlying principles of existence, destroyed the common lifestyle, world outlook, concepts of morality and faith, aggravating the crisis of consciousness typical for the turn of the $19^{\text {th }}-20^{\text {th }}$ centuries. It also triggered the search for a way out of crisis, development of new social, philosophic, moral and spiritual coordinates of existence.

As a result, it did not only strengthen the interest for historiosophical problems typical of Russian literature, but also developed a certain quality of artistic consciousness we refer to as historical consciousness. This term describes interconnection between artistic creativity and such universal category as the category of time.

Fiction literature plays a unique role in the development of historical consciousness, demonstrating the way different opinions on historical meaning were determined, the way they confronted and completed each other. At the same time, it is important to consider the peculiarities of literature inclined to historiosophical world outlook, not to any of the philosophical systems. The writer comprehends time aesthetically, within the framework of his artistic creation, "dissolving" historiosophical problems and transforming them in the emotional and expressive structure of his work. In literature historic facts and events, certain philosophical theories are of secondary significance; they are important for the writer only as a trigger for contemplations of man and history, of psychology and life of the "historical person" spirit. Historic events and reflections are refracted in artistic speech, becoming an internal feature of the text, shaped into an artistic image. The philosopheme of history unwinds in the text by means of some artistic techniques, such as spatial and temporal arrangement, character description, manner of narration, motives, symbolism etc.

It was the history, comprehended, experienced and revived in artistic texts, that influenced the whole Russian literature of the $20^{\text {th }}$ century, by determining not only the problematic and historical dominant of the artistic activity and increasing philosophic potential of literature, but also by formulating the basic principles for depicting the world, personality, establishing preferences in the selection of genre, style, conditional idioms, i.e. the solutions of creative tasks.

This article does not aspire to analyse and evaluate the historiosophical search of Pilnyak (for it is an object for historical science). It is focused on the research of the artistic codes, revealing the author's individual view of the historical period he lived in.

\section{Historical views of B. Pilnyak through the eyes of critics}

The way the work of B. Pilnyak was perceived and assessed in different years is pretty revealing. The first collections of short stories by B. Pilnyak were published in the years of the Revolution, so the young author was recognized both as the successor of the classic tradition, and a representative of the new art that destructed

it. The peculiarities of the writer's artistic world 
were regarded in different contexts. Speaking of Pilnyak's common interest for the universal laws of existence, "natural repetitiveness" of the world, connection between man and nature, attention for the subconscious, he was associated with the names of Dostoevsky, Chekhov, Bunin, Andreev, Sologub, Zaytsev. Remarking his ability of describing provincial scenery, Russian everyday life, reminding of some folklore motives, critics drew his literary genealogy from Pechersky, Remizov, and Zamyatin. But as it was the time to criticize the bright experiments of Pilnyak, the list of his literary teachers was completed with Blok, and, particularly, Bely, since the thesis of his strong influence on Pilnyak's style was rightfully, though importunately repeated by multiple researchers. That was when the thesis of A. Auer was proven: Pilnyak's poetics really shows a dialogue almost with the whole body of Russian classics (Auer, 1991: 8).

However, the writer had his own concept of following his teachers: contemplating over the specificities of literary work, he spoke of "conciliarity" ("our fate is to create Russian literature in the conciliar way"). In the period of triumph of collectivist ideas (Mayakovski, Malyshkin, Serafimovich etc.), Pilnyak chose a term originating from the Orthodox context. Another line of succession was found by I. Shaytanov: in Pilnyak's inclination to repetition and quoting texts by other authors in his works, he found "a peculiar spiritual of folklore" as a distinctive feature of literary consciousness of the post-revolutionary era (Shaytanov, 1991: 14).

However, noticing the writer's "affinity" for his teachers, from the very beginning the critics appreciated the originality of Pilnyak, who had always mastered the tradition in his own manner. It was clear that he had chosen his own way, but there were different opinions on where that way went and what the underlying meaning of his search was. As for the historical concept, its presence had been doubted, for the originality of the author's understanding of historical events had been underestimated for many years.

The official point of view was formulated by Leon Trotsky as early as in the 1920s, when he wrote that talented Pilnyak "lacks the idea of our time", and "historical philosophy of Pilnyak is absolutely retrogressive" in general (Trotsky, 1991: 72, 74). A. Voronsky, who contributed to the impartial assessment of the writer's prose more than anyone else, had also noticed that Pilnyak's books have "something that is not limited to a single world outlook, artistically incomplete and not thought through" (italics by L.T.) (Voronsky, 1987: 247). Among the contemporaries' opinions of Pilnyak as the "physician of the people's life" and the "annalist of the revolution", the observations of N. Kovarskiy are true revelations. He paid attention to the "sense of history" of the writer and demonstrated how his specific "hyperbolized historicism" manifests itself at the level of text and phrase (Kovarskiy, 1928: 75). But this understanding was not supported by his contemporaries. In the 1920s, books were interpreted, first of all, within the ideological framework. Even later, researchers preferred to stick to the opinion of the writer's poetization of spontaneity of the Revolution, its "animal" face, of his depiction of the Revolution as the people's rebellion, of the triumph of nature, physiological instincts, the "leather jackets" as the symbol of absence of any psychologism in the description of the main revolutionary characters (Gura, 1968). Such narrowness of perception is, first of all, caused by the ideology: long-lasting ruling of the only officially recognized idea of depicting history is more than typical for the Revolution period. Except for social realism, no other artistic trends, movements, or styles were encouraged, developed or studied. The consequences of this situation for literature 
were bravely and accurately formulated by S. Sheshukov (Sheshukov, 1970: 341).

But even the researchers who fairly admitted the non-canonical depiction of the Revolution time B. Pilnyak's prose before the 1920s, normally arrived at the conclusion on the outof-history world outlook of the writer. G. Belaia, who was the first to emphasize the thought on the historiosophical inclination of the 1920s prose, believed that "the historicism of Pilnyak is beyond any social specificity". According to the researcher, cognizing the national component of the Russian revolution was challenging for Pilnyak, for in his aspiration to "grasp the phenomenon of the national spirit in the Russian revolution" he relied "only (underlined by L.T.) on physiology of people's life". "In the works of Pilnyak, wholeness appears only in the search for organic and biologically simple things, but physiology is not an appropriate key to the social problems set by the Russian Revolution", concludes G. Belaia (Belaia, 1989: 143, 148-149).

Sticking to the tendency common for literary criticism, M. Golubkov remarked that "The Naked Year" novel provides no point of view on the happening that could combine the incompatible: the "leather jackets", or Bolsheviks, and the outrage of Russian self-will; Kitay-gorod and a merchant's banya; a heated freight car and a provincial merchant's house. "Only the presence of such compositional point of view that could express the ideological focus of the text, a sort of coordinate axis, able to unite and explain the phenomena arranged by Pilnyak within the epic space of his books, could bring the composition into a better organized shape, to put the separate fragments of story into an order" (Golubkov, 1995: 4-5).

In our opinion, the point of view on the events that make Pilnyak's books look as a single whole, does exist, but it is not the point. The writer really does not consider the social aspect of the Revolution, not to mention the aspect of any ideology. In his "Extracts from diary" written in 1923, he made the following provocative statement: " $<\ldots>$ I do not admit that I should be a communist and write in the communist manner $<\ldots>$ But I do admit that the fate of Russian Communist Party for me matters far less than the fate of Russia" (Pilnyak, 1994: I, 481-482).

" $<\ldots>$ My thoughts are out-of-history, and they are wrong; it is the key that unlocks romanticism in history $\langle\ldots\rangle$, is the way B. Pilnyak assesses his historiosophical search himself. He also explains: "I measured it with a different scale" (Pilnyak, 1993: 140, 142). The scale he speaks of is not ideological; it is historiosophical. In the famous trinity of "The Naked Year" ("Russia. Revolution. Blizzard") the author brings "Russia" to the fore. The originality of B. Pilnyak manifests itself not in the virtuoso description of the "Revolution blizzard", but in the desire to understand "what Russia cries out to the world" and to formulate this understanding through the techniques of writing.

\section{Artistic codes of the historiosophy of B. Pilnyak}

In the very first novel by the writer titled "The Naked Year", the base for the artistic structure of the text was a specific view on the historical fate of Russia, on the Revolution as the "stage on the post-chaise route of history", one link in the chain. The author's concept is expressed through a system of artistic techniques revealing historiosophical meanings.

One of the major images in this aspect is the multi-layered and an incredibly dynamic image of time. The apparent disorderliness, "whirledness" of the text is a well-planned technique intended to reflect the rhythm of the period. The historical reality itself broke the rhythm of moderation. Depicting time, B. Pilnyak does not use any end-to-end storyline; he shows no consistent 
development of some events based on the cause-and-effect relationships. Everything, from the euphony, description of certain details of the Revolution years to the "fragmentary" composition based on shifting temporal layers, broken storylines, abrupt changes in the fates of characters, the associative, not logical connection between parts of the story, the motion of conceptual and metaphoric rows, serves the task of creating a visible, moving, sound image of the Revolution time.

The novel composition has its internal logic. The conceptual concentres, not matching the formal chapters and corresponding to the temporal modality (past, present, and future) are clearly seen. The use of symbolic and metaphoric poetics is obvious, turning the artistic image of time into the symbol of the historical path of the country (which pushed E. Skorospelova to the conclusion on the neo-mythological character of Pilnyak's novel reproducing the historiosophical myths of Russia (Skorospelova, 2003: 119).

Existing in the present ("physiology of people's life" of 1919), Russia both bears the past (the pre-Peter Russia and, further, preMongolian, pagan, "izba" Russia) and is focused on the future. In the text structure, these temporal categories do not exist on their own and they do not gradually interchange. The dynamics of history, its controversial motion ais conveyed through the continuous shifts between different temporal and spatial scenes. The action is moved from Prikamye to Moscow, to Ilyinka and to Kitaygorod, then to Kanavino, into the steppe, then unwinds in former merchants' and noblemen's houses and an anarchist community, in peasants' izbas and on board a train, at a factory restored by the Bolsheviks, at the diggings of a burial mound, at a monastery, at a sectaries' shelter. This is the way the author creates his image of Russia carried away with the revolutionary blizzard and tumultuous reorganization of life.
The dynamics of history, its controversial motion is conveyed through the continuous shifts between different temporal and spatial scenes. In the name of the town (Ordynin), in the characters' names (the Ordynins, the Ratchins) we hear motives of the hard historical lot (orda: the Horde, rat' - army, the "eternal fight"). The combinations of Russian names (Gleb, Boris etc.) and "Asian" last names (referring to "Tartars", "Asians") embody the historiosophical opposition of West and East. Certain historical categories correlate with the generally philosophical ones (passing minutes - and the eternity, the present and the future, life - and death), which reveals the Revolution time in a broad historical and philosophical context.

The novel is polyphonic, giving the floor to many characters, through the eyes and through the mind of whom ("Through the eyes of Andrei", "Through the eyes of Natalia", "Through the eyes of Irina") it reflects a number of historiosophical ideas that had been bothering Russia for almost two centuries after Peter's reforms. The modernity correlates to old traditions, psychology, habits and customs going back to the ancient pagan times. The present time bears the experience of the past century, and even the revolutionary Russia keeps the history "with its Time of Troubles, Razinov and Pugachev's rebellions, with the Seventeenth century, with the old churches, icons, legends, rituals, Juliana of Lazarevo and Andrei Rublev, its forests and steppes, moors and rivers, water and forest spirits". Pilnyak's image of time is the interaction of the centuries: "the Time of Trouble", "Pugachev and Razin's rebellions", "the Seventeenth century"; mentioned water and forests spirits, legends and rituals turn us to the ancient Rus, the churches and icons remind of the Orthodox Russia. Stylization of the text into a ritual, or a fairy tale, just like any other sort of stylization (annals, fable, Bible) create the artistic image of the people's Russia. The times 
are inseparable from space (forests, steppes, moors, rivers), and all this cosmos is united and organized under the concept of "Russia".

One of the major artistic codes is hidden in the title of the novel, "The Naked Year". It is the entwinement of the mundane (revolutionary years, cold, hunger, death) and the existential components. Back in the beginning of the century, in his "In Lower Depths", Gorky wrote the words that formulated the existential problem of the critical historical epoch: "We're all of us, nothing but the bare, naked man". What is the man like, not only in the "depths" of life, out of familiar connections, family and society, but in the "depths" of the soul, in his metaphysical "bareness"? What is the man's nature? According to B. Pilnyak, the Revolution broke the "scab" of the former norms and traditions, peeled all the unnatural off, opening up the natural base, up to the instincts, the primary, the savage, the animal roots. That is how it opened the way to "living", to the non-distorted origins, the man, and the world his is inseparable of, where he had lived for ages and centuries. What is it like, the world, the natural and the historical? What is the true Russia like, where are its living roots? That is how the original principle of Pilnyak's artistic thinking is formed: the doubtless combination of the social and the natural, of the temporary and sustainable in man and time. The conceptual structure of the books is based on the intertwining "natural" (blizzard, fire, smells) and "historical" metaphors (minute, year, clock chimes, old burial mound). The metaphoric character of all the elements expressing historiosophical problems leads to the conclusion that a metaphor is the major means of artistic thinking of history.

A. Voronsky wrote that Pilnyak's historiosophy peacefully combines "muzhiks' anarchism, the bolshevism of the 1918, the specific revolutionary Slavophilism, and Populism" (Voronsky. "On the edge": 119). In the 1920, the time of cruel fight against religion, the critics could not speak of the Orthodox layer of Pilnyak's historical concept. The image of the Mother of God as the key to understanding Russia appears on the pages of his books more than once. In the final of "The Naked Year", at the wedding ceremony, the newlyweds are blessed with one of the most respected Russian icons, the Kazan icon of the Mother of God. Considering the Orthodox context (the Mother of God as the protectrix of Russia) and the literary traditions Pilnyak relies on (Blok's "flowing transformation" of the image of woman - Russia - revolution - history), we may say that the Christian component as an integral part of the historical fate of Russia is present in Pilnyak's concept, forming the author's idea of resurrection through the "absinthial bitterness" of adversity, suffering, and death.

\section{The opposition of East and West in the concept of Russia's historical way}

The criticism expressed by the Russian immigration drew special attention to the fact that the works by Pilnyak and other similar writers developing the motive or Russia's originality (L. Leonov, K. Fedin etc.) lie in the line of Eurasian ideas (Struve, 1956: 43). The metaphor of the "oriental" element as a part of history, culture and psychology of the Russian people was the image of Kitay-gorod, continuing the "Scythian" symbolism of Russian literature (the "Scythian" motives in a historiosophical text from the ancient to contemporary times will be later described by I. Brazhnikov (Brazhnikov, 2011)).

"Third Capital" novel title is symbolic: it is determined by the contemplations of Russian culture on the place of Russia in the world history, of Russia as "the third Rome". The historiosophical basis of the book is underlined by the separated space of the novel ("Europe, 
Russia, world"; "the interplanetary vacuum") and the characteristics of the antagonists ("there are no heroes. Russia, Europe, world, faith, faithlessness, - culture, blizzards, storms; the image of the Mother of God" (Pilnyak, 1993: 140).

The book is distinguished with the emphasized storylessness and herolessness, broken motives and associations, combination of fragmentary parts of plot. "The wolves' world fight and the Russian time of Trouble", a truly global chaos reigning the world is expressed in the poetics of the book. The main character of the novel is the thought of the author, often unexpressed, appearing as a guess, association, dream, coincidence, transfiguration. The fragments of the text are structurally formulated units of the author's thought. The "brain game" is a way of free, almost unmotivated transition from the contemplations on the "Asian" nature of Russia to the description of European life, from the immigrants' life episodes to disputes of Russia. The opinion of the author is personified in one of the characters of the book: "I, Pilnyak".

The contrast of the two worlds, Russia and Europe, is revealed in the persistent repetitions of some certain motives: warmth, satiety, comfort, electricity, shine, conservative traditions blizzard, "Russian rebellion", typhoid, starvation (1921!), "Russian Asia", where the will of action is "cramping tense". The "pseudonyms" of the Europe-Russia motive are the typical foreign Smith and Emelyan Emelyanovich Razin, a combination of the name, patronymic and the last name, hyperbolically expressing the motive of the Russian rebellion.

Concealing nothing, from the "new birth epopee" to cannibalism, "demonism, blizzards, storms", the author arrives at the conclusion: "I know: Russia will start off renovated..." This conviction is based on the "hypothesis of the eternity" formulated in the novel. Its meaning is to recognize the free will of people to build their own lives to be the driving force of history. The author reveals his own hypothesis both logically and metaphorically: "I know: all living, just like the earth in springs, shall die to be reborn over and over again" (Pilnyak, 1992: 141). Just like in "The Naked Year", the main means of historical thinking for the author is a metaphor. The Earth, the most relevant metaphor of "The third capital", conveys the universal connection of the man, nature and the world. The structure of the text often includes the oxymoron principle, the combination of incompatible phenomena: the crusting snow in March and bitter birches in June, blood and life, dirt and cleanness, the Lent and the youth, women tempting men with their flesh. They are united by the terms "land", "Russia", "Revolution" and the joyful anticipation of the real life.

The image of the earth appears in the author's definition of immigration as "tu-zemye" (literally from Russian; "there-landness"). This metaphoric line establishes the idea of Moscow, Russia as the centre which concentrates the thoughts, feelings, hopes of different people. Among the immigrants, there are some real characters: Pitirim Sorokin, whose report on Russia and its role in the global culture was stylized by B. Pilnyak; Ivan Bunin, whose "Gentleman from San Francisco" was later caricatured by Pilnyak. The apocalyptic pictures presented by the immigrants look vague in comparison with the story by Vs. Ivanov of starvation in the revolutionary Russia. "Life is mixed with death, man is mixed with beasts and nature which "breaths its eternal, not manmade smells right into the human heart", this description written by Vs. Ivanov, an author close to B. Pilnyak, can be easily referred to B. Pilnyak (Miliukov, 1930-1937: 429). One may think that the only conclusion made of all this in Europe and immigration is that the nation and the state had died. But it is followed by the episodes that 
prove: Russia still has the power to live and create, "despite of everything, notwithstanding anything". That is what it "cries out to the world" (Pilnyak, 1993: 138).

\section{Conclusion}

Therefore, the writer remained faithful to the idea of Russia and the Revolution as one of its links for the whole of his lifepath. Returning to the problems, conflicts and images of his first novel, he will clarify some separate aspects of the concept.

The Revolution in Pilnyak's books is not a certain social phenomenon. The writer did not focus on the impartial depiction, say nothing of the description of the "driving force" of the Revolution, its "conscious" origin opposing nature (of the absence of which he had always been reproached). Here the personal perception, experience, and comprehension come to the fore. According to Pilnyak, the Revolution is "the time when only two things matter: life and death", "the days when you need to live: now or never" (Pilnyak, 1994: I, 77). In his vision, the revolution is a universal phenomenon, opposing to the equally universal state of entropy. Making a break, losing will, energy to act and to create through the destruction of the still, expired century means dying in the artistic world of Pilnyak.

In the books by Pilnyak, landscape metaphors acquire a special historiosophical meaning. The most typical example is the image of blizzard, the main motive of the writer's creation. "Over the land there's blizzard, there's freedom, there's revolution!" "No one knows how to spell correctly: bliozzard or blizzard", - writes the author in the epigraph to the same-name short story (Pilnyak, 1991: 164). This seemingly random phrase explains the meaning of Pilnyak's favourite metaphor: according to Dal, "bliozzard" and "riot" are related ("miatel" and "metel" in Russian).
The artist cognizes time through the aesthetic means, under the laws of artistic creation. His text shows an obvious aesthetic structure, a literary experiment (sometimes laboured). The traditional constructions of classic prose, such as genre, narration, plot, are destroyed or transformed. "The realism is not primitive, it is not realia, but realiora: shift, distortion, flexion, non-objectiveness" is the way E. Zamyatin characterizes new art (neorealism) (Zamyatin, 436). The euphony, symbolism, vocabulary use, imagery, syntax, the "fragmented" composition are all united under the task of creating a visible, moving, sound image of the "splashed time". This is how the poetics of avant-guarde, educated by the lessons of symbolism, "opens the window" into the ontological depth of the author's artistic world.

The absence of any end-to-end narration is compensated with a system of theme lines, based on expansive metaphors. The leading theme line (the "blizzard") is completed and supported with the images of flood, fire, anxious red colour, darkness ("mist, haze, daze"), absinthial bitterness, cleaning storms, living and dead water. Repeating and varying, getting a little closer only due to the associations, the metaphor act as the links of the storyline, bringing the artistic matter of the book into a single whole. The "metaphor lace" making the book integrate, creates a unique stylistic pattern, a bright and expressive ornament. At the same time, they convey the historiosophical problems, emotions and moods caused by some certain events. The remarked specificity of the style proves the formation of a sustainable stylistic tendency referred to as ornamentalism ("ornamental prose" in the narrow meaning).

The use of metaphoras a way of contemplating over history is typical for Russian cultural tradition. The reasons for this phenomenon were formulated by I. Shaytanov: "Russian historical thought has always been inclined to expressing 
itself through metaphors for a number of reasons: for having been used to being cautious and discreet; for being driven out through literature, for being born in it" (Shaytanov, 1991: 20).

We cannot but remark that after the boom of Pilnyak research at the turn of millennia there was a "research silence". Conference proceedings remain the main publication genre (Institute of World Literature, Kolomna). A significant contribution was made by the publication of Pilnyak's letters, prepared by Institute of World Literature of Russian Academy of Sciences with the support of the writer's successors (Pilnyak, 2010). It helped to extend the historical and philosophic context, bringing the previously unknown materials to the annals of science.

Today we witness the need for the return to the books of B. Pilnyak in order to "trace $<\ldots>$ Russian historical fates" (Pilnyak, 1994: I, 481482) and to ensure that "the main chapter" of history happened in Russia (from the letter to D. Lutokhin, 1923). It coincides with the modern stage of finding the national identity, values and meanings.

\section{References}

Andronikashvili-Pilnyak, B., Pilnyak, B.A. (2000). Russkie pisateli 20 veka: Biograficheskiy slovar' [Russian writers of the 20 th century: Biographic dictionary], compiled and edited by P.A. Nikolaev. Moscow: Bol'shaia rossiyskaia entsiklopediia; Randevu. 553-555.

Andronikashvili-Pilnyak, K. (1997). "Solianoy ambar” B. Pil'niaka (zamysel i istochniki romana) [B. Pilnyak's "salt barn" (the concept and origins of the novel)]. Author's extract from the thesis for the academic degree of the Candidate of Philology. Moscow: Institute of World Literature of Russian Academy of Sciences.

Anpilova, L. (2008). Proza Borisa Pil'niaka 1920-kh godov. Opyt russkogo ekspressionizma [B. Pilnyak's prose of the 1920s. Russian expressionism experience]. Yekaterinburg: Ural State Pedagogical University. $162 \mathrm{p}$.

Auer, A. (1991). O poetike Borisa Pil'niaka [On poetics of B. Pilnyak], In B.A. Pil'niak. Issledovaniia i materialy: Mezhvuz. sb.nauch. trudov [B.A. Pil'niak. Research and materials. Intercollege collection of research works]. Volume 1. Kolomna: Kolomna Pedagogical Institute. 4-15.

Auer, A. (2009). "Pered litsom vechnosti..." Stat'i o khudozhestvennom mire B.A. Pil'niaka [In the face of eternity...”. Collection of articles on the artistic world of B.A. Pilnyak]. Kolomna: Kolomna State Pedagogical Institute. 212 p.

Belaia, G. (1989). Don-Kikhoty 20-kh godov: "Pereval” i sud'ba ego idey [The Don Quixotes of the 1920s. The "Passover" and the fate of his ideas]. Moscow: Sov. pisatel'. 400 p.

Boris Pilnyak (1928). Stat'i i materialy [Articles and materials], edited by B.V. Kazansky and Iu.N. Tynianov. Leningrad: Academia (Mastera sovremennoy literatury. III).

Boris Pil'niak: opyt segodniashnego prochteniia [Boris Pilnyak: experience of contemporary interpretation] (1995). Collection of articles. Moscow: Nasledie. 208 p.

Brazhnikov, I. (2011). Istoriosofskiy tekst russkoy revoliutsii $v$ khudozhestvennoy literature $i$ publitsistike XX veka [Historiosophic text of the Revolution in fiction and non-fiction literature of the $20^{\text {th }}$ century]. Author's extract from the thesis for the degree of the Doctor of Philology. Moscow: Moscow State Pedagogical University.

Voronov, V. (1991). Otvergnutaia Pravda. O literature 20-kh godov [The rejected truth. On literature of the 1920s], In Literatura $v$ shkole [Literature at school], 2. 25-34. 
Voronskiy, A. (1923). Na styke [On the borderline]. Moscow - Pg.

Voronskiy, A. (1927). Literaturnye tipy [Literary types]. Moscow: Krug.

Voronskiy, A. (1987). Boris Pil'niak [Boris Pilnyak], In Voronskiy A. Iskusstvo videt' mir [Voronskiy, A. The art of seeing the world]. Moscow.

Golubkov, M. (1995). Esteticheskaia sistema v tvorchestve Borisa Pil'niaka 20-kh godov [Aesthetic system in the works of B. Pilnyak of the 1920s], In Boris Pil'niak: Opyt segodniashnego prochteniia [Boris Pilnyak: experience of contemporary interpretation]: Collection of articles. Moscow: Nasledie. 3-10.

Gofman, V. (1928). Mesto Pil'niaka [The place of Pilnyak], In Boris Pil'niak. Stat'i i materialy [Boris Pilnyak: articles and materials], edited by B.V. Kazanskiy and Iu.N. Tynianov. Leningrad: Academia (Mastera sovremennoy literatury. III). 7.

Griakalova, N. (2001). Istoricheskaia real'nost' i prostranstvo teksta (Istoriosofskaia kontseptsiia Borisa Pil'niaka nachala 1920-kh gg.) [Historic reality and text medium (Historiosophical concept of Boris Pilnyak of the early 1920s), In Literatura i istoriia. Istoricheskiy protsess v tvorcheskom soznanii russkikh pisateley i mysliteley XVIII-XX v.v. [Literature and history. Historical process in the creative consciousness of Russian writers and thinkers of the $18^{\text {th }}-20^{\text {th }}$ centuries]. Volume 3. Saint Petersburg: Nauka. 414-445.

Griakalova, N. (2005). Pil'niak B. [Pilnyak B.], In Russkaia literatura XX v. Prozaiki, poety, dramaturgi: Biogr.slovar' [Russian literature of the 20 th century: Prose writers, poets, playwrights. Biographic dictionary]: in 3 volumes. Edited by N.N. Skatov. Volume 3. Moscow: OLMA-PRESS Invest. 62-64.

Gura, B. (1968) Roman i realizm: Puti razvitiia sovetskogo romana v literature 1917-1929 godov [Novel and realism: Ways of development of the Soviet novel in the 1917-1929 years' literature]. Author's extract from the thesis for the degree of Doctor of Philology. Moscow, 11-12, 15.

Zamiatin, E. (1923). O literature, revoliutsii, entropii i o prochem [On literature, revolution, entropy and other], In Zamiatin E.I. Izbrannye proizvedeniia [Zamyatin E.I. Selected works]. Moscow: Sov. Rossiia, 1990. 431-437.

Zen'kovskiy, V. (1991). Istoriia russkoy filosofii [History of Russian philosophy]. Volume 1. Part 1. Leningrad.

Kovarskiy, N. Svidetel'skoe pokazanie [A witness' evidence], In Boris Pil'niak [Boris Pilnyak], edited by B.V. Kovarskiy and Iu.N. Tynianov. Leningrad: Academia (Mastera sovremennoy literatury. III).

Karpenko, I.E. (1993). Sistema iazykovykh izobrazitel'nykh sredstv ornamental'noy prozy B. Pil'niaka [The linguistic expressive system of the ornamental prose by B. Pilnyak]. Author's extract from the thesis for the degree of the Candidate of Philology. Moscow: People's Friendship University of Russia.

Literaturnaia zhizn' Rossii 1920-kh godov. Sobytiia. Otzyvy sovremennikov. Bibliografiia [Literature life of the 1920s Russia. Events. Comments of contemporaries. References]. Volume 1. Part 2. Moscow and Petrograd. 1921-1922. (2005) Moscow: Institute of World Literature of Russian Academy of Sciences. 704 p.

Miliukov, P. (1930-1937). Ocherki po istorii russkoy kul'tury [Essays on Russian culture history]. Volumes 1-3. Paris. 
Nirman Boramiak-Barburach (1991). B.A. Pil'niak i "peterburgskiy tekst" [B.A. Pilnyak and the "Petersburg text"], In B.A. Pil'niak. Issledovaniia i materialy [B.A. Pilnyak. Research and materials], intercollege collection of works. Volume 1. Kolomna: Kolomna Pedagogical Institute. 36-46.

Pil'niak, B. (1991). Povesti i rasskazy. 1915-1929 [Novels and short stories. 1915-1929]. Compiled, introduction and remarks by I.O. Shaytanov, text preparation by B.B. Andronikashvili-Pilnyak. Moscow: Sovremennik, $687 \mathrm{p}$.

Pil'niak. B. (1992). Tret'ia stolitsa: Povesti i rasskazy [The third capital: novels and short stories]. Compiled, introduction by B.B. Anrdonikashvili-Pilnyak, remarks by K.B. Andronikashvili-Pilnyak. Moscow: Russkaia kniga. 448 p.

Pil'niak, B. (1994). Sochineniia v 3-kh t. [Collection of works in three volumes]. Compiled, prepared, remarks by B.B. Andronikashvili-Pilnyak. Moscow: Lada M.

Profatilo, I. (2006). Khudozhestvennyy mir prozy B.A. Pil'niaka [Artistic world of prose by B.A. Pilnyak]. Author's extract from the thesis for the degree of Candidate of Philology. Moscow: Moscow State Pedagogical University, 2006.

Skorospelova, E. (2003). Russkaia proza XX veka: ot A. Belogo ("Peterburg") do B. Pasternaka ("Doktor Zhivago") [Russian prose of the $20^{\text {th }}$ century: from A. Bely ("Petersburg") to B. Pasternak ("Doctor Zhivago")]. Moscow: Teis, 2003. 115-132.

Struve, G. (1956). Russkaia literature v izgnanii: Opyt istoricheskogo obzora zarubezhnoy literatury [Russian literature in exile: Foreign literature historical review experience]. New York.

Tamarchenko, N. (1991). “Golyy god” B. Pil'niaka kak khudozhestvennoe tseloe [“The Naked Year" by B. Pilnyak as an artistic whole], In B.A. Pil'niak. Issledovaniia i materialy [B.A. Pilnyak: Research and materials], intercollege collection of works. Volume 1. Kolomna: Kolomna Pedagogical Institute. 16-26.

Trotsky, L. (1991). Literatura i revoliutsiia [Literature and revolution]. Moscow.

Trubina, L. (1993). "Nesvoevremennye mysli” Borisa Pil'niaka [The "untimely thoughts" of Boris Pilnyak], In V poiskakh istiny: Lit.sbornik v chest' 80-letiia prof. S.I. Sheshukova [Searching for truth: literature collection published in commemmoration of the 80-th birthday of Professor S.I. Sheshukov]. Moscow: Prometey. 113-118.

Trubina, L. (1999). Istoricheskoe soznanie v russkoy literature pervoy treti XX veka: Tipologiia. Poetika [Historical consciousness in Russian literature of the first third of the $20^{\text {th }}$ century: Typology. Poetics]. Author's extract from the thesis for the degree of the Doctor of Philology. Moscow: Moscow State Pedagogical University.

Trubina, L. (2001). K voprosu o prirode antinomii Rossiia-Zapad v istoriosofskoy kontseptsii Borisa Pil'niaka [To the question on the nature of Russia-West antinomy in the historiosophical concept of Boris Pilnyak], In B.A. Pil'niak. Issledovaniia i materialy [B.A. Pilnyak: Research and materials], Intercollege collection of works. Volumes III-IV. Kolomna: Kolomna State Pedagogical Institute. 67-73.

Trubina, L. (2006). "Glavnaia glava istorii - v Rossii”: Obraz vremeni v tvorchestve Borisa Pil'niaka [The main chapter of history took place in Russia": The image of time in the works by Boris Pilnyak, In Literatura v shkole [Literature at school]. 4. 9-13.

Shaytanov, I. (1991a). Metafory Borisa Pil'niaka, ili Istoriia v lunnom svete [Metaphors of Boris Pilnyak, or History under moonlight], In Pil'niak, B. Povesti i rasskazy 1915-1929 [Pilnyak, B. Novels and short stories. 1915-1929]. Moscow: Sovremennik. 5-36. 
Shaytanov, I. (1991b). Istoricheskie metafory Borisa Pil'niaka ("Krasnoe derevo" i "Volga vpadaet v Kaspiyskoe more") [Historical metaphors of Boris Pilnyak ("Mahogany" and "The Volga falls to the Caspian Sea"], In B.A. Pil'niak. Issledovaniia i materialy [B.A. Pilnyak. Research and materials]. Intercollege collection of works. Kolomna. 47-56.

Shalamov, V. (1987). Dvadtsatye gody (zametki studenta MGU) [The twenties (notes of a Moscow State University student)], In Iunost' [The Youth], 11.

Sheshukov, S. (1970). Neistovye revniteli. Iz istorii literaturnoy bor'by 20-kh godov [The frantic zealots. From the history of literary struggle of the 1920s]. Moscow: Mosk. rabochiy. $352 \mathrm{p}$.

\title{
Художественные коды исторического сознания в прозе Бориса Пильняка
}

\author{
Л.А. Трубина \\ Московский педагогический государственный \\ университет \\ Россия, 119991, Москва, ул. М. Пироговская, 1
}

В статье рассматривается творчество известного в 1920-е г2. писателя-авангардиста Б. Пильняка. Перспективу современного прочтения прозы мастера автор статьи видит в исследовании связи его формальных экспериментов с онтологической проблематикой. В этом Пильняк одновременно продолжает традищию классики и вступает в диалог с ней, разрушает классическую форму.

Акцент делается на исследовании художественных кодов, раскрывающих историческое сознание автора. В ијентре - самобытный взгляд Пильняка на историю России, определяющий стилевые особенности его произведений. «Монтажная» композиция, элементы «мозговой игры»,, система лейтмотивов создают образ «взвихренного» времени. Историософская проблематика раскрывается через метафоризацию хронотопа, сочетание «природных» и «исторических» метафор, символизацию заголовков, фамилий и имен, стилизаџию фольклора и православной образности.

Ключевые слова: Борис Пильняк, литература 1920-х г2., авангард, орнаментальная проза, историософия, историческое сознание, метафора, лейтмотив, символ, образ времени.

Научная специальность: 10.00.00 - филологические науки. 